\title{
Protein v. enzymic protein hydrolysates. Nitrogen utilization in starved rats
}

\author{
BY JULIO J. BOZA', OLGA MARTÍNEZ-AUGUSTIN²*, LUIS BARÓ2, \\ M. DOLORES SUAREZ1 AND ANGEL GIL ${ }^{2}$ \\ ${ }^{1}$ Department of Biochemistry and Molecular Biology, University of Granada, Spain \\ ${ }^{2}$ PULEVA Research and Development Department, Granada, Spain
}

(Received 4 April 1994 - Revised 19 May 1994 - Accepted 7 June 1994)

\begin{abstract}
The present study was carried out to compare the effects of four isoenergetic and isonitrogenous diets on the $\mathbf{N}$ utilization, total serum protein concentration and serum amino acid profile in starved rats at weaning. These diets differed only in the molecular form of two milk proteins (whey protein and casein), which were either native or partly hydrolysed. Male Wistar rats at weaning were fasted for $3 \mathrm{~d}$ and then refed with one of the four diets for $48 \mathrm{~h}$. No differences were observed in the body weight gain, protein digestibility and total serum protein concentration between groups after the refeeding period and all the $\mathbf{N}$ balances were positive. $\mathbf{N}$ retention was higher in the two groups of rats given the protein-hydrolysatebased diets compared with those given the intact-protein-based diets. This was associated with a lower urinary $\mathbf{N}$ excretion in rats, given the whey-protein-hydrolysate and the casein-hydrolysate diets. Despite this fact, the serum amino acid pattern of rats given the hydrolysed protein diet was very similar to that of those given the corresponding native protein diet. In conclusion, we have proved that enzymic hydrolysates from milk proteins have equivalent effects to native proteins in recovery after starvation in rats at weaning, on $\mathbf{N}$ absorption, total serum protein concentration and serum amino acid profile, and even give a higher $\mathbf{N}$ retention. We did not observe any harmful effect in using protein hydrolysates instead of native proteins.
\end{abstract}

Protein: Nitrogen: Starvation

Starvation, as well as certain gastrointestinal disorders, affects the functionality of the small intestine (Firmansyah et al. 1989), and specifically the peptidase activities of the enterocyte brush border (Hatch, 1981). Thus, if the protein of a diet was partly hydrolysed or replaced with amino acids, this could improve $\mathrm{N}$ absorption in patients whose intestinal function is impaired through significant loss of digestive function (Grimble \& Silk, 1989). Di- and tripeptides can be absorbed intact by a system which is different from any amino acid transporter and are hydrolysed intracellularly (Grimble et al. 1986; Hoshi et al. 1988). Likewise, in several human and animal meal-feeding studies the rate of absorption of individual amino acid residues was faster from enzymic hydrolysates than from an equivalent free amino acid mixture (Silk et al. 1980; Grimble \& Silk, 1986), apart from the advantage of the lower osmolarity of the protein hydrolysates compared with the free amino acid mixtures (Brinson et al. 1989).

Several studies have shown that enzymic protein hydrolysates rich in di- and tripeptides have similar or even higher nutritional values compared with those of their native proteins (Poullain et al. 1989; Rouanet et al. 1990).

The present study was carried out to compare the effects of four isoenergetic diets differing only in the molecular form of two milk proteins (whey protein and casein), which

* For reprints. 
were either native or partly enzymically hydrolysed, on the $\mathrm{N}$ utilization, total serum protein concentration and serum amino acid profile in starved rats at weaning.

\section{METHODS}

\section{Enzymic hydrolysis of milk proteins (whey protein and casein)}

Whey proteins were hydrolysed by the action of a mixture of pancreatic proteolytic enzymes (20-80 Anson units/g; Novo, Bagsvaed, Denmark) as described previously (Boza, 1992). Enzymic hydrolysis of casein was carried out using the mixture of pancreatic proteolytic enzymes from Novo and a protease from Bacillus licheniformis, Protease MKC 660L ( 0.83 Anson units $/ \mathrm{ml})$, supplied by Kalichemie Iberia (Barcelona, Spain), as described previously (Boza, 1992). The mean molecular weight distribution (Table 1) was determined by exclusion HPLC (Knights, 1985). No significant differences were observed in the amino acid profiles of the hydrolysates compared with those of their respective native proteins (Boza, 1992).

\section{Diets}

Four semipurified standard diets $(200 \mathrm{~g}$ protein $/ \mathrm{kg})$ were prepared following the recommendations of the Institute of Laboratory Animal Resources (1979), differing only in their protein source: whey protein (WP), whey-protein hydrolysate (WPH), casein (C) or casein hydrolysate $(\mathrm{CH})$. The chemical composition of the diets is given in Table 1.

\section{Animals and experimental design}

Male Wistar-strain rats aged $21 \mathrm{~d}$ and weighing about $60 \mathrm{~g}$ were used. They were housed individually in metabolism cages (Lagoplast, Madrid, Spain) in a room maintained at $22^{\circ}$, with alternating $12 \mathrm{~h}$ periods of light and dark. The experimental group of rats consisted of twenty-eight rats starved for $72 \mathrm{~h}$ with free access to water and to $\mathrm{NaCl}$ solution $(3 \mathrm{~g} / \mathrm{l})$. Rats were then randomly allocated to one of the four experimental diets and fed for $48 \mathrm{~h}$. Animals were pair-fed by restricting the oral intake of the animals in the group which had eaten the greatest quantity of food on the first day. The protocol of the study was approved by the Animal Ethics Committee of the University of Granada and all the experiments were done in the Department of Biochemistry and Molecular Biology of the same University.

Complete faecal and urine collections were made during the refeeding period $(48 \mathrm{~h})$. Metabolism cages specially designed for the separate collection of faeces and urine avoiding faecal and urine contamination from food spillage were used. Faeces were then dried in an oven at $80^{\circ}$. Diets, faeces and urine were analysed for $\mathrm{N}$ by the Kjeldahl method (Association of Official Analytical Chemists, 1984).

After the experimental period, rats were killed by decapitation under Nembutal anaesthesia and $2 \mathrm{ml}$ blood samples were collected. Serum was prepared and stored at $-30^{\circ}$ until required. Total serum proteins were measured by a Biuret colorimetric assay using bovine serum albumin as a standard (McMurray, 1988).

Serum amino acid analysis was carried out as described by Scholze (1985) and modified by us as follows. Serum was mixed with $0.4 \mathrm{~mm}$-methionine sulphone used as internal standard, in the proportions $1: 1(\mathrm{v} / \mathrm{v})$. A portion of the mixture, usually $100 \mu \mathrm{l}$, was ultrafiltered in a membrane tube (No. PGLC 10000; Millipore, Milford, MA, USA). Of this ultrafiltered solution, $25 \mu \mathrm{l}$ was dried under vacuum at a pressure lower than $9.33 \mathrm{~Pa}$ (70 mTorr); $10 \mu \mathrm{l}$ of a methanol-triethanolamine-water solution $(2: 2: 1$, by volume) were added and samples were dried further. Then, $20 \mu \mathrm{l}$ of the reagent mixture composed of methanol-water-phenylisothiocyanate-triethanolamine $(7: 1: 1: 1$, by volume) were added and the mixture was left to react for $20 \mathrm{~min}$, after which the excess of the reagent mixture was removed by vacuum drying for $90 \mathrm{~min}$. Finally, the phenyl carbamil 
Table 1. Composition of the diets $(\mathrm{g} / \mathrm{kg})$

\begin{tabular}{|c|c|c|c|c|}
\hline Diet... & $\begin{array}{l}\text { Whey protein } \\
\text { (WP) }\end{array}$ & $\begin{array}{c}\text { Whey-protein } \\
\text { hydrolysate (WPH)* }\end{array}$ & $\begin{array}{l}\text { Casein } \\
\text { (C) }\end{array}$ & $\begin{array}{c}\text { Casein } \\
\text { hydrolysate }(\mathrm{CH})^{*}\end{array}$ \\
\hline \multicolumn{5}{|l|}{ Ingredients } \\
\hline WP & 317.0 & - & - & - \\
\hline WPH & - & $328 \cdot 0$ & - & - \\
\hline $\mathrm{C}$ & - & - & $225 \cdot 0$ & - \\
\hline $\mathrm{CH}$ & - & - & - & $229 \cdot 0$ \\
\hline Soya-bean oil & $38 \cdot 0$ & 37.0 & $50 \cdot 0$ & $50 \cdot 0$ \\
\hline Cellulose & $50 \cdot 0$ & 500 & $50 \cdot 0$ & $50 \cdot 0$ \\
\hline Maize starch & 478.7 & $471 \cdot 7$ & $555 \cdot 5$ & 557.5 \\
\hline Sucrose & $100 \cdot 0$ & $100-0$ & $100 \cdot 0$ & $100 \cdot 0$ \\
\hline Choline chloride & 1.0 & $1 \cdot 0$ & 1.0 & $1 \cdot 0$ \\
\hline $\mathrm{NaCl}$ & $0 \cdot 3$ & - & 1.7 & - \\
\hline $\mathrm{K}_{2} \mathrm{HPO}_{4}$ & $1 \cdot 5$ & - & $4 \cdot 4$ & - \\
\hline $\mathrm{Ca}_{2} \mathrm{HPO}_{4}$ & 11.0 & $10 \cdot 0$ & $9 \cdot 9$ & 9.9 \\
\hline Mineral mix $\dagger$ & $2 \cdot 3$ & $2 \cdot 3$ & $2 \cdot 3$ & $2 \cdot 3$ \\
\hline Vitamin mix & $0 \cdot 3$ & $0-3$ & 0.3 & 0.3 \\
\hline \multicolumn{5}{|c|}{ Chemical composition $(\mathrm{g} / \mathrm{kg})$} \\
\hline Protein & 208 & 206 & 200 & 204 \\
\hline Fat & 53 & 54 & 57 & 57 \\
\hline Carbohydrate & 635 & 635 & 621 & 617 \\
\hline Ash & 26 & 35 & 34 & 49 \\
\hline Moisture & 78 & 70 & 88 & 73 \\
\hline
\end{tabular}

* The molecular weight distributions of the protein hydrolysates were (\%); WPH: > 30000 Da $8 \cdot 3$, $800-8000 \mathrm{Da} 44 \cdot 3,200-800 \mathrm{Da} 44 \cdot 5,<200 \mathrm{Da} 2 \cdot 9 ; \mathrm{CH}: 800-2500 \mathrm{Da} 13 \cdot 3,200-800 \mathrm{Da} 72 \cdot 1,<200 \mathrm{Da} 14 \cdot 6$.

$\dagger$ Contained (/kg diet): $\mathrm{MgSO}_{4} 1.8 \mathrm{~g}, \mathrm{Fe}$ lactate $2 \mathrm{H}_{2} \mathrm{O} 0.2 \mathrm{~g}, \mathrm{ZnCO}_{3} 56 \mathrm{mg}, \mathrm{CuSO}_{4} 14 \mathrm{mg}, \mathrm{KIO}_{3} 0.4 \mathrm{mg}$, $\mathrm{Na}_{2} \mathrm{SeO}_{8} 0.4 \mathrm{mg}, \mathrm{KCr}\left(\mathrm{SO}_{4}\right)_{2} 19 \mathrm{mg}$.

$\ddagger$ Contained (/kg diet): thiamin hydrochloride $1.8 \mathrm{mg}$, riboflavin $1.8 \mathrm{mg}$, pyridoxine hydrochloride $21 \mathrm{mg}$, nicotinic acid $9 \mathrm{mg}$, calcium D-pantothenate $4.8 \mathrm{mg}$, pteroylmonoglutamic acid $0.6 \mathrm{mg}$, D-biotin $60 \mu \mathrm{g}$, cyanocobalamin $3 \mu \mathrm{g}$, retinol acetate $4.2 \mu \mathrm{g}$, cholecalciferol $7.5 \mu \mathrm{g}$, tocopherol $1.5 \mathrm{mg}$, menadione $7.5 \mu \mathrm{g}$.

derivatives were frozen at $-30^{\circ}$ until analysis. Immediately before the analysis, samples were dissolved in $100 \mu 15 \mathrm{~mm}-\mathrm{Na}_{2} \mathrm{HPO}_{4}(\mathrm{pH} \mathrm{7.4)}$.

Amino acid analysis was performed by HPLC using a Waters (Milford, MA, USA) system including two pumps, Model 510, and injector U6K and UV detector, Model 481 which was monitorized at $254 \mathrm{~nm}$.

The amino acid derivatives were separated on an octadecylsilyl reversed phase Pico-tag column (Waters) using an elution programme consisting of two solvents: (A) $70 \mathrm{~mm}$ -

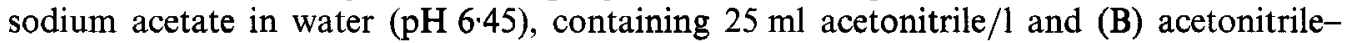
water-methanol (45:40:15, by volume). Gradient mixing was as follows: $0-13.5 \mathrm{~min}, 0 \%$ B; 13-5-24 min, 6\% B; 24-30 min, 9\% B; 30-50 min, 34\% B; 50-60 min, 36\% B; $60-60.5 \mathrm{~min}, 100 \% \mathrm{~B}$, held at $100 \% \mathrm{~B}$ for $5 \mathrm{~min}$ and $67 \mathrm{~min}, 100 \% \mathrm{~A}$.

\section{Statistical analysis}

Student's $t$ tests were used to determine mean differences among the groups for all the variables studied (Dixon et al. 1990). A probability level of $P<0.05$ was considered as significant.

\section{RESULTS}

Table 2 summarizes food intake, body-weight gain, $\mathrm{N}$ digestibility and total serum protein concentrations. Average body weight after the starvation at the start of refeeding was $35 \cdot 1$ 
Table 2. Feed intake, body-weight gain, nitrogen digestibility and total serum protein concentrations in starved rats refed for $48 \mathrm{~h}$ with diets containing whey protein $(W P)$, wheyprotein hydrolysate $(\mathrm{WPH})$, casein $(\mathrm{C})$ or casein hydrolysate $(\mathrm{CH})^{*}$

(Mean values with their standard errors for seven rats per dietary group)

\begin{tabular}{|c|c|c|c|c|c|c|c|c|}
\hline & \multicolumn{2}{|c|}{ WP $(n 7)$} & \multicolumn{2}{|c|}{ WPH $(n 7)$} & \multicolumn{2}{|c|}{$C(n 7)$} & \multicolumn{2}{|c|}{$\mathrm{CH}(n 7)$} \\
\hline & Mean & SE & Mean & $\mathrm{SE}$ & Mean & $\mathrm{SE}$ & Mean & SE \\
\hline Feed intake $(g / 24 h)$ & 6.7 & $0 \cdot 3$ & 6.9 & 0.2 & $7 \cdot 1$ & 0.2 & 6.9 & 0.2 \\
\hline Body-weight gain $(\mathrm{g} / 24 \mathrm{~h})$ & $4 \cdot 3$ & $0 \cdot 4$ & 4.5 & 0.2 & $4 \cdot 0$ & 0.2 & $4 \cdot 1$ & 0.5 \\
\hline Nitrogen digestibility $(\%) \dagger$ & $95 \cdot 8$ & 1.0 & $94 \cdot 0$ & 1.5 & $93 \cdot 4$ & 0.9 & $94 \cdot 3$ & $1 \cdot 2$ \\
\hline Serum total protein $(\mathrm{mg} / \mathrm{l})$ & 47 & 6 & 50 & 6 & 44 & 5 & 44 & 1 \\
\hline
\end{tabular}

* For details of diets and procedures, see Table 1 and p. 66.

+ Calculated as $((\mathrm{N}$ intake - faecal $\mathrm{N}) / \mathrm{N}$ intake $) \times 100$.

Table 3. Nitrogen intake, nitrogen output (stool and urine) and nitrogen retention $(\mathrm{mg} / 24 \mathrm{~h})$ in starved rats refed for $48 \mathrm{~h}$ with diets containing whey protein $(W P)$, whey-protein hydrolysate $(W P H)$, casein $(C)$ or casein hydrolysate $(\mathrm{CH}) \ddagger$

(Mean values with their standard errors for seven rats per dietary group)

\begin{tabular}{|c|c|c|c|c|c|c|c|c|}
\hline & \multicolumn{2}{|c|}{$\mathrm{WP}(n 7)$} & \multicolumn{2}{|c|}{ WPH $(n 7)$} & \multicolumn{2}{|c|}{$\mathrm{C}(n 7)$} & \multicolumn{2}{|c|}{$\mathrm{CH}(n 7)$} \\
\hline & Mean & $\mathrm{SE}$ & Mean & SE & Mean & SE & Mean & SE \\
\hline Intake (mg/24 h) & $216 \cdot 4$ & $8 \cdot 9$ & $224 \cdot 8$ & $5 \cdot 2$ & $223 \cdot 1$ & $6 \cdot 5$ & $220 \cdot 4$ & 5.9 \\
\hline Stool loss (mg/24 h) & $9 \cdot 0$ & $1 \cdot 0$ & $13 \cdot 5$ & 1.8 & $14 \cdot 7$ & $1 \cdot 2$ & $12 \cdot 6$ & $2 \cdot 5$ \\
\hline Urinary loss (mg/24 h) & $110 \cdot 6$ & $4 \cdot 7$ & $91 \cdot 6$ & $8 \cdot 0$ & $117 \cdot 8$ & $6 \cdot 3$ & $90 \cdot 5$ & $7 \cdot 5$ \\
\hline $\mathrm{N}$ retention $(\mathrm{mg} / 24 \mathrm{~h})$ & $96 \cdot 7$ & $5 \cdot 2$ & $119 \cdot 6^{*}$ & $7 \cdot 8$ & $90 \cdot 5$ & $6 \cdot 3$ & $117 \cdot 2 \dagger$ & $5 \cdot 2$ \\
\hline
\end{tabular}

* Mean value was significantly different from that of the WP group $(P<0.05)$.

+ Mean value was significantly different from that of the $\mathrm{C}$ group $(P<0.05)$.

\$ For details of diets and procedures, see Table 1 and p. 66.

(SE 2-1) g. Refed rats showed a similar body-weight gain regardless of the diet used. There were no significant differences between groups with respect to the total serum protein concentration and all the diets were equally digested.

Table 3 shows the $\mathrm{N}$ intake, excretion (faeces and urine) and retention in $\mathrm{mg} / 24 \mathrm{~h}$. Rats fed on one of the two diets containing hydrolysed protein exhibited lower $\mathbf{N}$ urinary losses and higher $\mathrm{N}$ retention than rats fed on the respective diets containing native proteins.

As shown in Table 4 the serum free amino acid profile of rats given the hydrolysed-whey formula was very similar to that exhibited by the rats fed on the whey-protein formula, with the only exception of the higher threonine values of the latter. A similar pattern was observed in rats fed on casein or hydrolysed-casein formula. In this case, higher values of citrulline and arginine were seen in the serum of rats fed on the casein-hydrolysate diet.

Compared with the casein (native or hydrolysed)-fed rats, those fed on the whey-protein (native or hydrolysed) diets had higher threonine, isoleucine, aspartic acid and glutamic acid, and lower glutamine, proline and tyrosine serum levels. The non essential:essential amino acid ratio was slightly higher in the two groups fed on the casein (native or hydrolysed) diets compared with the whey-protein (native or hydrolysed) diets. 
Table 4. Serum free amino acid concentrations ( $\mu m o l / l)$ in starved rats after refeeding for $48 \mathrm{~h}$ with diets containing whey protein $(W P)$, whey-protein hydrolysate $(W P H)$, casein $(C)$, or casein hydrolysate $(\mathrm{CH}) \ddagger$

(Mean values with their standard errors for seven rats per dietary group)

\begin{tabular}{|c|c|c|c|c|c|c|c|c|}
\hline \multirow[b]{2}{*}{ Amino acid } & \multicolumn{2}{|c|}{$\mathrm{WP}(n 7)$} & \multicolumn{2}{|c|}{ WPH $(n 7)$} & \multicolumn{2}{|c|}{$\mathrm{C}(n 7)$} & \multicolumn{2}{|c|}{$\mathrm{CH}(n 7)$} \\
\hline & Mean & $\mathrm{SE}$ & Mean & SE & Mean & $\mathbf{S E}$ & Mean & $\mathbf{S E}$ \\
\hline Asp & 67 & 6 & 57 & 6 & 29 & 5 & 27 & 9 \\
\hline Asn & 267 & 38 & 235 & 24 & 211 & 32 & 224 & 6 \\
\hline Glu & 401 & 20 & 416 & 73 & 203 & 30 & 157 & 28 \\
\hline Gln & 349 & 57 & 349 & 56 & 667 & 53 & 609 & 23 \\
\hline Gly & 250 & 13 & 269 & 18 & 222 & 22 & 233 & 38 \\
\hline Ala & 1074 & 77 & 735 & 80 & 758 & 64 & 906 & 135 \\
\hline Ser & 320 & 8 & 336 & 34 & 252 & 13 & 280 & 32 \\
\hline Thr & 891 & 123 & $540^{*}$ & 59 & 263 & 21 & 276 & 40 \\
\hline Lys & 507 & 39 & 463 & 50 & 563 & 80 & 413 & 130 \\
\hline His & 23 & 3 & 35 & 4 & 64 & 7 & 66 & 9 \\
\hline Cit & 136 & 44 & 116 & 35 & 77 & 12 & $147 \dagger$ & 52 \\
\hline Arg & 168 & 10 & 162 & 10 & 76 & 16 & $121 \dagger$ & 7 \\
\hline Ile & 244 & 89 & 181 & 19 & 121 & 19 & 132 & 15 \\
\hline Leu & 165 & 33 & 144 & 18 & 192 & 27 & 169 & 20 \\
\hline Val & 303 & 18 & 251 & 23 & 322 & 34 & 396 & 57 \\
\hline Tyr & 66 & 7 & 56 & 2 & 123 & 18 & 148 & 20 \\
\hline Phe & 57 & 8 & 91 & 19 & 73 & 22 & 85 & 6 \\
\hline Trp + Orn & 50 & 6 & 44 & 5 & 119 & 22 & 102 & 23 \\
\hline Met & 80 & 14 & 91 & 10 & 76 & 9 & 92 & 16 \\
\hline Cys & 75 & 26 & 90 & 58 & 92 & 30 & 47 & 45 \\
\hline Tau & 21 & 3 & 34 & 3 & 28 & 3 & 29 & 3 \\
\hline Pro & 342 & 44 & 230 & 44 & 442 & 77 & 695 & 113 \\
\hline OH-Pro & 57 & 31 & 25 & 4 & 23 & 3 & 39 & 14 \\
\hline Non essential :essential & 1.6 & 0.2 & 1.9 & 0.2 & $2 \cdot 1$ & $0 \cdot 3$ & $2 \cdot 5$ & 0.2 \\
\hline
\end{tabular}

* Mean values was significantly different from that of the WP group $(P<0.05)$.

$\dagger$ Mean values were significantly different from those of the $C$ group $(P<0.05)$.

‡ For details of diets and procedures, see Table 1 and pp. 66-67.

\section{DISCUSSION}

In protein-energy malnutrition there is reduced pancreatic enzyme secretion with reduced dipeptide hydrolase ( $E C$ 3.4.13.11) and increased risk of transfer of intact proteins across the small-intestinal mucosa (Iyngkaran et al. 1991), thus supporting the use of a hypoallergenic diet during the rehabilitation of severely malnourished patients. These hypoallergenic diets may have two possible $\mathrm{N}$ sources : free amino acid mixtures or protein hydrolysates. The former have the advantage of a perfectly reproducible composition and avoid any possibility of antigenic risk. However, they have some disadvantages such as a high osmolarity with a risk of complicating osmotic diarrhoea and they are known to be absorbed at a slower rate than protein hydrolysates (Linblad, 1978).

The present experiment was carried out principally to study the effects of two milkprotein hydrolysates as $\mathrm{N}$ sources in the diet compared with the native proteins in starved rats. The four diets were isoenergetic and had the same protein content $(200 \mathrm{~g} / \mathrm{kg})$, which is quite high compared with normal diets $(100-120 \mathrm{~g} / \mathrm{kg})$. It is well known that an intake of dietary protein in excess of individual requirements permits the uptake of amino acids for nutritional recovery from protein-energy malnutrition even in the face of impaired 
absorptive efficiency, and the unabsorbed nitrogenous materials remain relatively innocuous (Solomons et al. 1989).

In the present study there were no differences in food consumption or body-weight gain between groups, or in the $\mathrm{N}$ digestibility and the concentration of total serum protein after a $2 \mathrm{~d}$ refeeding period after starvation. Our results are in agreement with those reported by Poullain et al. (1989), who studied the effects of whey protein, its enzymic hydrolysate and free amino acid mixtures in starved rats. However, these authors observed a higher total serum protein concentration in the group which was fed on the whey-protein-hydrolysate diet.

Concerning $\mathrm{N}$ balance, all the rats were in positive balance. $\mathrm{N}$ faecal excretion was similar in all groups, showing that starvation did not affect the rate of $\mathrm{N}$ absorption from the gut irrespective of the molecular form of the $\mathrm{N}$ source, suggesting a rapid increase in the efficiency of protein digestion and absorption, taking into account the fact that digestibility values in all groups were very similar to those observed in normal growing rats given the same $\mathbf{N}$ source (Boza, 1992). However, the two groups of rats fed on proteinhydrolysate diets showed lower urinary $\mathrm{N}$ losses compared with those fed on the diet containing the protein in the native form. These results are also supported by the work of Poullain et al. (1989) who demonstrated lower urinary $\mathrm{N}$ losses in starved rats fed on a whey-protein-hydrolysate-based diet compared with those including the native protein or even the elemental form (free amino acid mixtures). Poullain et al. (1989) explained this fact in terms of the faster absorption rate of amino acids when the $\mathrm{N}$ source is small peptides rather than protein or free amino acids, which could affect protein synthesis, mainly in the enterocyte cell. This hypothesis is supported by the evidence of significantly higher jejunum mucosa protein content found in starved rats refed on protein-hydrolysate-based diets compared with those refed on intact-protein-based diets (Boza, 1992).

The serum amino acid profile depends on the amino acid composition of the diet and the rate of absorption (Rigo \& Senterre, 1987). In the present study we observed hardly any difference in the serum concentration of amino acids depending on the molecular form of the $\mathrm{N}$ source (native protein or enzymic hydrolysate), which is logical considering that we did not observe any significant differences in the amino acid pattern between milk proteins (whey protein or casein) and their respective hydrolysates (Boza, 1992). In spite of the fact that $\mathrm{N}$ retention was higher in all rats fed on enzymic-hydrolysate diets, this difference did not significantly affect the serum amino acid concentrations or the non-essential:essential amino acid ratio. These results are in agreement with those reported by Rouanet et al. (1990) in growing rats fed on a diet based on bovine plasma proteins or an enzymic hydrolysate of these proteins, who only observed a slight difference between the serum amino acid profile of both groups, suggesting a near quantitative utilization of amino acids. We detected hyperaminoacidaemia in the serum of the rats given either whey or casein (native or hydrolysed) due to the high content of $\mathrm{N}$ in our experimental diets $(200 \mathrm{~g} / \mathrm{kg})$, unlike the results obtained in the study of Rouanet et al. (1990).

Concerning the protein type (whey protein or casein), irrespective of the molecular form, the non-essential: essential amino acid ratio was slightly lower in the groups fed on whey protein than in those fed on casein, because of the better amino acid profile of the whey proteins. Likewise, rats fed on whey-protein (native or hydrolysed)-based diets showed higher values for serum threonine than those fed on casein-based diets. This fact is thought to be due to the high content of threonine in the whey proteins and the immaturity of the threonine enzymic pathway during early life (Rigo et al. 1989).

In conclusion, we have shown that enzymic hydrolysates from milk proteins have effects equivalent to those of the native protein in recovery after starvation in rats at weaning, on $\mathrm{N}$ absorption, total serum protein concentration and serum amino acid profile, and even 
cause a higher $\mathrm{N}$ retention. We did not observe any harmful effect in the use of protein hydrolysates instead of native proteins.

\section{REFERENCES}

Association of Official Analytical Chemists (1984). Official Methods of Analysis, pp. 303-304. Arlington: Association of Official Analytical Chemists.

Boza, J. J. (1992). Obtención de hidrolizados enzimáticos de proteínas lácteas. Estudio del valor nutritivo y de la capacidad antigénica. (Obtention of enzymic milk protein hydrolysates. Nutritional value and antigenic capacity studies). $\mathrm{PhD}$ Thesis, University of Granada, Spain.

Brinson, R. R., Hanumanthu, S. K. \& Pitts, W. M. (1989). A reappraisal of the peptide-based enteral formulas: clinical applications. Nutrition in Clinical Practice 4, 211-217.

Dixon, W. J., Brown, M. B., Engelman, L. \& Jennrich, R. I. (1990). BMDP Statistical Software Manual. Berkeley: University of California Press.

Firmansyah, A., Suwandito, L., Penn, D. \& Lebenthal, E. (1989). Biochemical and morphological changes in the digestive tract of rats after prenatal and postnatal malnutrition. American Journal of Clinical Nutrition 50, $261-268$.

Grimble, G. K., Keohane, P. P., Higgins, B. E., Kaminski, M. V. \& Silk, D. B. A. (1986). Effect of peptide chain length on amino acid and nitrogen absorption from two lactoalbumin hydrolysates in the normal human jejunum. Clinical Science 71, 65-69.

Grimble, G. K. \& Silk, D. B. A. (1986). The optimum form of dietary nitrogen in gastrointestinal disease: proteins, peptides or amino acids. Verhandlungen der Deutschen Gesellschaft für Innere Medizin 92, 674-685.

Grimble, G. K. \& Silk, D. B. A. (1989). Peptides in human nutrition. Nutrition Research Reviews 2, 87-108.

Hatch, T. F. (1981). Effects of protein-calorie malnutrition on the digestive and absorptive capacities of infants. In Textbook of Gastroenterology and Nutrition in Infancy, pp. 767-777 [E. Lebenthal, editor]. New York: Raven Press.

Hoshi, T., Abe, M. \& Nunukawa, T. (1988). Physiological mechanisms of intestinal absorption of protein hydrolysates and their relevance to bacterial growth in small intestine. Bifidobacteria Microflora 7, 29-34.

Institute for Laboratory Animal Resources (1979). Control of diets in laboratory animal experimentation. Nutrition Abstracts and Reviews: Livestock Feed and Feeding 49, 413-419.

Iyngkaran, N., Yadav, M. \& Boey, C. G. (1991). Intestinal brush border peptidases in cow's milk protein-sensitive enteropathy. Acta Paediatrica Scandinavica 80, 549-550.

Knights, R. (1985). Processing and evaluation on the antigenicity of protein hydrolysates. In Nutrition for Special Needs in Infancy. Protein Hydrolysates, pp. 105-115 [F. Lifishitz, editor]. New York: Marcel Dekker.

Linblad, B. S. (1978). Free amino acid diets in the vicious circle of diarrhoea-malnutrition-malabsorption during infancy. Acta Paediatrica Scandinavica 67, 393-396.

McMurray, J. (1988). Plasma proteins. In Practical Clinical Biochemistry, pp. 401-435 [A. H. Gowenlock, editor]. Oxford: Heinemann Professional Publishing.

Poullain, M. G., Cezard, J. P., Roger, L. \& Mendy, F. (1989). Effect of whey proteins, their oligopeptide hydrolysates and free amino acid mixtures on growth and nitrogen retention in fed and starved rats. Journal of Parenteral and Enteral Nutrition 13, 382-386.

Rigo, J. \& Senterre, J. (1987). Significance of plasma amino acid pattern in preterm infants. Biology of the Neonate 52, S41-S49.

Rigo, J., Verloes, A. \& Senterre, J. (1989). Plasma amino acid concentrations in term infants fed human milk, a whey-predominant formula, or a whey hydrolysate formula. Journal of Pediatrics 115, 752-754.

Rouanet, J. M., Zambonino Infante, J. L., Caporiccio, B. \& Peojan, C. (1990). Nutritional value and intestinal effects of dipeptides and tripeptides. Annals of Nutrition and Metabolism 34, 175-182.

Scholze, T. (1985). Determination of phenylthiocarbamil amino acids by reversed-phase high-performance liquid chromatography. Journal of Chromatography. 350, 453-460.

Silk, D. B. A., Fairclough, P. D., Clark, M. L., Hegarty, J. E., Marrs, T. C., Addison, J. M., Burston, D., Clegg, K. M. \& Matthews, D. M. (1980). Uses of a peptide rather than a free amino acid nitrogen source in chemically defined elemental diets. Journal of Parenteral and Enteral Nutrition 4, 548-553.

Solomons, N. W., Molina, S. \& Bulux, J. (1989). Effect of protein-energy malnutrition on the digestive and absorptive capacities of infants and children. In Textbook of Gastroenterology and Nutrition in Infancy, 2nd ed., pp. 517-533 [E. Lebenthal, editor]. New York: Raven Press. 